Crop Breeding and Applied Biotechnology 14: 23-28 2014

Brazilian Society of Plant Breeding. Printed in Brazil

\title{
ARTICLE
}

\section{Diallel analysis of maize inbred lines for grain yield, oil and protein content.}

Amir José Klein Werle ${ }^{1}$, Fernando Rafael Alves Ferreira ${ }^{1}$, Ronald José Barth Pinto ${ }^{*}$, Claudete Aparecida Mangolin ${ }^{1}$, Carlos Alberto Scapim ${ }^{1}$ and Leandro Simões Azeredo Gonçalves ${ }^{1}$

Received 04 May 2013

Accepted 03 December 2013

\begin{abstract}
This study aimed to investigate the combining ability and heterotic effects on grain yield (GY), oil content (OC) and crude protein $(C P)$ in tropical and temperate maize lines. Hybrids and inbred lines were evaluated in a complete diallel scheme without reciprocals, in two experiments in randomized blocks with three replications. The partitioning of the sum of squares for general (GCA) and specific (SCA) combining ability indicated that both additive and non-additive effects were involved in the genetic control of the studied traits. The estimates of the quadratic components showed predominance of non-additive genetic effects in the trait control. However, for $O C$ and $C P$, the non-additive effect had a clearly negative influence on the hybrid combinations. The cross $L_{6} x L_{10}$ was considered promising, because it associated RG positively with BP and OC.
\end{abstract}

Key words: Zea mays L.; combining ability, heterosis; Griffing method, plant breeding.

\section{INTRODUCTION}

Maize (Zea mays L.) is considered one of the major cereals in the world, with a production of 55.4 million tons of grain on an area of 12.7 million hectares in Brazil (FAO 2013). The economic importance of maize is due to the broad possibilities of use, in fresh or processed form. However, the development of increasingly productive maize hybrid varieties resulted in a loss of nutritional value, especially with decreases in protein and oil, due to the negative correlation with yield (Uribelarrea et al. 2004, Zhang et al. 2008, Bueno et al. 2009).

Starch, protein and oil content are the most important chemical storage components of maize. Maize kernels contain $70-75 \%$ starch, $8-10 \%$ protein and $4-5 \%$ oil (Boyer and Hannah 2001). The maize proteins can be divided into classes according to their solubility. In maize, the concentration of the $\alpha$-zein protein is highest, representing $50-60 \%$ of the total protein. Although the $\alpha$-zein is poor in essential amino acids such as lysine and tryptophan, the protein fractions in grains are not constant and can vary according to the grain type and be changed by mutant genes (Prasanna et al. 2001).

Among the different mutant genes that modify the maize grain quality, the opaque -2 gene is one of the best known. Its presence causes a reduction in $\alpha$-zein synthesis, thus resulting in an increase in $\beta$-zein fractions, an easier-todigest protein that makes these amino acids more readily available. However, the low seed density and soft texture of this mutant type are associated with some undesirable agronomic traits, including susceptibility to pests and to organisms causing cob rots, a lower drying rate, and a higher incidence of mechanical damage to grain at harvesting (Oliveira et al. 2004, Gibbon and Larkins 2005). With few exceptions, these mutants were not developed commercially by private companies, although several studies are designed to mitigate these problems (Gupta et al. 2009, Gutiérrez-Rojas et al. 2010). As a result of this research, we developed a new maize type called quality protein maize (QPM), which combines the nutritional excellence of maize opaque-2 with the grain structure of the commercial cultivars (Badu-Apraku and Lum 2010).

In animal feed, a high oil concentration in maize kernels is desirable due to the use as feed grains, since the calorific value of oil is higher than that of starch. Moreover, in human food, maize oil is well-accepted for cooking, because of the high content of unsaturated fatty acids, resulting in low

\footnotetext{
${ }^{1}$ Universidade Estadual de Maringá (UEM), Departamento de Agronomia, Avenida Colombo 5790, Maringá, 87.020-900, PR, Brazil

${ }^{2}$ Universidade Estadual de Londrina (UEL), Departamento de Agronomia, Rodovia Celso Garcia Cid, PR 485 km 380, Campus Universitário, Londrina, 86.057-970, PR, Brazil. *E-mail: rjbpinto@uem.br
} 
cholesterol levels when metabolized (Mangolin et al. 2004). However, as the increase in the seed oil content is usually accompanied by a decrease in seed mass, the reduction in grain yield is a limiting factor to a more the widespread use of hybrid maize with high oil content (Misevic et al. 1989).

The genetic variability for grain quality traits is considered low in temperate maize germplasm (Osorno and Carena 2008). In this context, cooperation efforts between public and private bodies involved in the project Maize Germplasm Improvement (GEM) include the introduction of tropical germplasm to broaden the genetic base.

The introduction of tropical into temperate plant germplasm can not only broaden the genetic base of breeding programs, but also increase the adaptability of new hybrids (Fan et al. 2003). However, little effort has been made to assess the grain quality in tropical lines and their combining ability with temperate lines. Accordingly, the purpose of this study was to investigate the effect of combining ability and heterosis of tropical and temperate maize lines on the grain, oil and protein content.

\section{MATERIAL AND METHODS}

The plant material consisted of 12 parental lines and their non-reciprocal hybrids. The parents belong to a group of elite lines of an association between the State University of Maringá and Syngenta Seeds Ltd. The origin and other characteristics of the lines used are shown in Table 1.

The experiments of parent and hybrid evaluation were carried out private properties in Cascavel and Mauá da Serra, Paraná, according to the normally used cultural practices for maize cultivation under a high agro-technical level. The experiments were evaluated in a complete randomized block design with three replications, where each plot consisted of two 6-m long rows. Rows were spaced $0.6 \mathrm{~m}$ and plants 0.20 apart, with a total area of $7.2 \mathrm{~m}^{2}$.
The following traits were evaluated: i) grain yield (GY), from harvest with mechanical harvester equipped with a weighing system and moisture gauge, after moisture correction to $13 \%$ and conversion from $\mathrm{g} \mathrm{plot}^{-1}$ to $\mathrm{kg} \mathrm{ha}^{-1}$; ii) percentage of crude protein (CP), using the Kjeldahl method (Compêndio Brasileiro de Alimentação Animal 2009), and iii) oil content $(\mathrm{OC})$, using the Soxhlet method (Compêndio Brasileiro de Alimentação Animal 2009). The data of CP and $\mathrm{OC}$ were obtained from the analysis performed at the Laboratory of Animal Nutrition, Federal University of Paraná.

The GY, CP and OC data were subjected to analysis of variance (F test). Based on the analysis of variance, the sum of squares of the treatments was partitioned into general and specific combining ability (GCA and SCA, respectively), using method 2, in a fixed model, as defined by Griffing (1956). The average heterosis percentage among the variables was also analyzed, using software Genes (Cruz 2013) for all analyses.

\section{RESULTS AND DISCUSSION}

The effect of genotypes (lines + hybrids) was statistically significant for all traits, indicating a wide variability among the treatments (Table 2). The environments differed with regard to responses for grain yield and crude protein, but not for oil content. According to Jellum and Marion (1966), the oil content is much more related to the genotypes than the environment and is considered a trait with high heritability. The effects of the genotype-environment interaction were only significant for grain yield, indicating a differentiated genotype performance in response to environmental changes.

The mean CP of the parental lines was $10.28 \%$ for tropical and $9.53 \%$ for temperate lines. For the hybrids, the means of the groups of tropical $\mathrm{x}$ tropical, temperate $\mathrm{x}$ temperate and tropical $x$ temperate crosses were $8.91,8.88$ and $8.73 \%$, respectively. For oil content, the mean percentages of the lines were $4.26 \%$ for tropical and $4.25 \%$ for temperate.

Table 1. Characteristics of 12 maize inbred lines, used in the maize breeding program of the State University of Maringá and Syngenta Seeds Ltda

\begin{tabular}{lllll}
\hline Lines & Cycle & Adaptation & Group & Origin \\
\hline $\mathrm{L}_{1}$ & Super early & Temperate & Dent & Southern dent \\
$\mathrm{L}_{2}$ & Super early & Temperate & Flint & B73 \\
$\mathrm{L}_{3}$ & Super early & Temperate & Dent & Southern dent \\
$\mathrm{L}_{4}$ & Very early & Temperate & Flint & Lancaster \\
$\mathrm{L}_{5}$ & Very early & Tropical & Flint & Pop Suwan \\
$\mathrm{L}_{6}$ & Early & Temperate & Dent & Stiff Stalk Synthetic \\
$\mathrm{L}_{7}$ & Early & Temeprate & Dent & Stiff Stalk Synthetic \\
$\mathrm{L}_{8}$ & Early & Tropical & Dent & Tuxpeño \\
$\mathrm{L}_{9}$ & Early & Tropical & Dent & Tuxpeño \\
$\mathrm{L}_{10}$ & Early & Temperate & Flint & Non-Stiff Stalk Synthetic \\
$\mathrm{L}_{11}$ & Early & Tropical & Dent & Tuxpeño \\
$\mathrm{L}_{12}$ & Early & Tropical & Flint & Pop Suwan \\
\hline
\end{tabular}


The means of the cross groups tropical $x$ tropical, temperate $\mathrm{x}$ temperate and tropical $\mathrm{x}$ temperate were $3.93,4.29$ and $4.12 \%$, respectively. For grain yield, the means of the combinations tropical $\mathrm{x}$ tropical, temperate $\mathrm{x}$ temperate and tropical $x$ temperate were $8,651.85,10,310.32$ and $9,761.59$ $\mathrm{kg} \mathrm{ha}^{-1}$, respectively.

The partition of the sum of squares of genotypes in the sum of squares for general (GCA) and specific (SCA) combining ability showed that both GCA and SCA were significant, indicating that additive and non-additive effects were involved in the genetic control of these traits (Table 2). There were no significant interactions for GCA $\mathrm{x}$ Environments and SCA $\mathrm{x}$ Environments for protein and oil, indicating that the genetic effects remained constant in the tested environments. On the other hand, the interaction was significant for grain yield, requiring individual analysis of GCA and SCA for each environment.

The estimates of the quadratic components indicated

Table 2. Estimates of mean squares of corn genotypes and environments, general and specific combining ability (GCA and SCA) and of the error, estimates of quadratic components of the effects of combining ability and coefficient of variation (CV) for crude protein (PB), oil content (OC) and grain yield $(\mathrm{GY})$

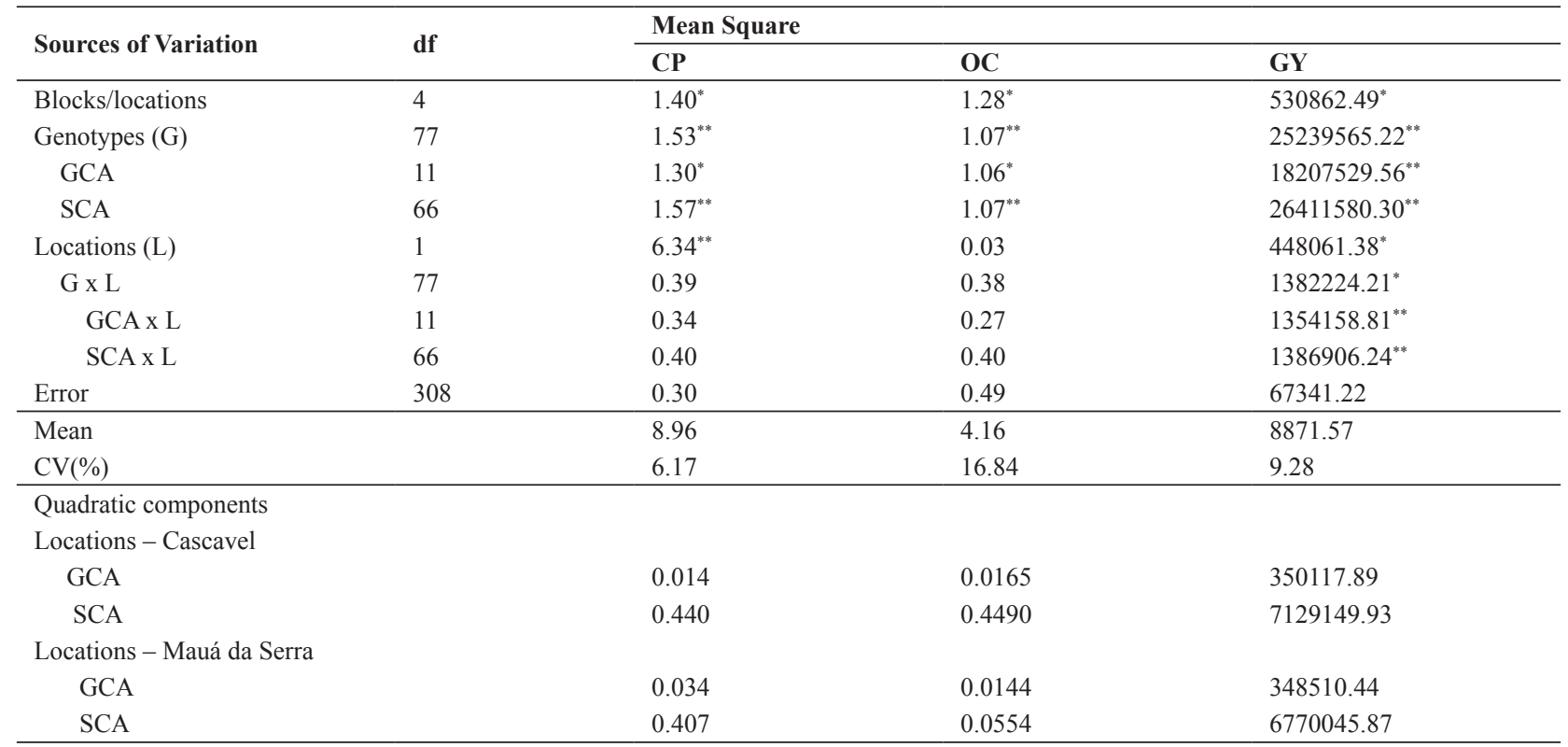

" and ${ }^{* *}$ significant at 1 and $5 \%$ probability, respectively.

Table 3. Estimates of the effects of general combining ability for crude protein (CP) oil content (OC) and grain yield (GY), evaluated in 12 maize inbred lines in a complete diallel scheme without reciprocals

\begin{tabular}{lllll}
\hline & \multicolumn{2}{l}{ Evaluated traits } & & GY \\
\cline { 2 - 4 } Parents & CP & OC & Cascavel & 196.077 \\
& & & 325.49 & 194.865 \\
$\mathrm{~L}_{1}$ & 0.043 & 0.112 & 301.71 & 618.361 \\
$\mathrm{~L}_{2}$ & -0.139 & 0.042 & 495.02 & 163.439 \\
$\mathrm{~L}_{3}$ & -0.32 & -0.063 & -0.154 & 925.608 \\
$\mathrm{~L}_{4}$ & -0.054 & 0.008 & 300.67 & 441.114 \\
$\mathrm{~L}_{5}$ & -0.065 & -0.262 & 736.58 & 278.553 \\
$\mathrm{~L}_{6}$ & 0.199 & 0.239 & 516.69 & -372.832 \\
$\mathrm{~L}_{7}$ & -0.039 & 0.026 & -415.817 & -340.699 \\
$\mathrm{~L}_{8}$ & -0.015 & -0.195 & -25.415 & -883.663 \\
$\mathrm{~L}_{9}$ & -0.016 & -0.097 & -445.874 & -142.395 \\
$\mathrm{~L}_{10}$ & 0.039 & 0.004 & -376.345 & -1078.428 \\
$\mathrm{~L}_{11}$ & 0.094 & 0.097 & -1412.573 & \\
$\mathrm{~L}_{12}$ & 0.273 & 0.088 & \\
\hline
\end{tabular}


AJK Werle et al.

a predominance of the non-additive genetic effects for all traits (Table 2). However, it is clear that for crude protein and oil content the non-additive effect influenced the hybrid combinations negatively. This result was corroborated by other studies that indicate a negative correlation of yield increase with the CP and OC (Prasanna et al. 2001, Oliveira et al. 2006).

The best lines for $\mathrm{CP}, \mathrm{L}_{12}(0.273)$ and $\mathrm{L}_{6}(0.199)$, had a good overall performance in the test environments (Table $3)$. Line $\mathrm{L}_{6}$ had the highest positive GCA for oil content, with 0.239 , followed by the lines $\mathrm{L}_{1}, \mathrm{~L}_{11}$ and $\mathrm{L}_{12}$ with 0.112 , 0.097 and 0.088 , respectively. Note that the lines $\mathrm{L}_{6}$ and $\mathrm{L}_{12}$ obtained the best GCA values for CP and OC. However, only line $\mathrm{L}_{6}$ obtained positive values of GCA for grain yield, ranking first in Cascavel and third in Mauá da Serra. In Mauá da Serra, lines $\mathrm{L}_{5}$ and $\mathrm{L}_{3}$ had the highest GCA values, with 925.61 and 618.36 , respectively.

With regard to the specific combining ability $\left(\mathrm{S}_{\mathrm{ij}}\right)$ of the hybrids derived from the crosses tropical $\mathrm{x}$ tropical $\left(\mathrm{L}_{5} \mathrm{x}\right.$
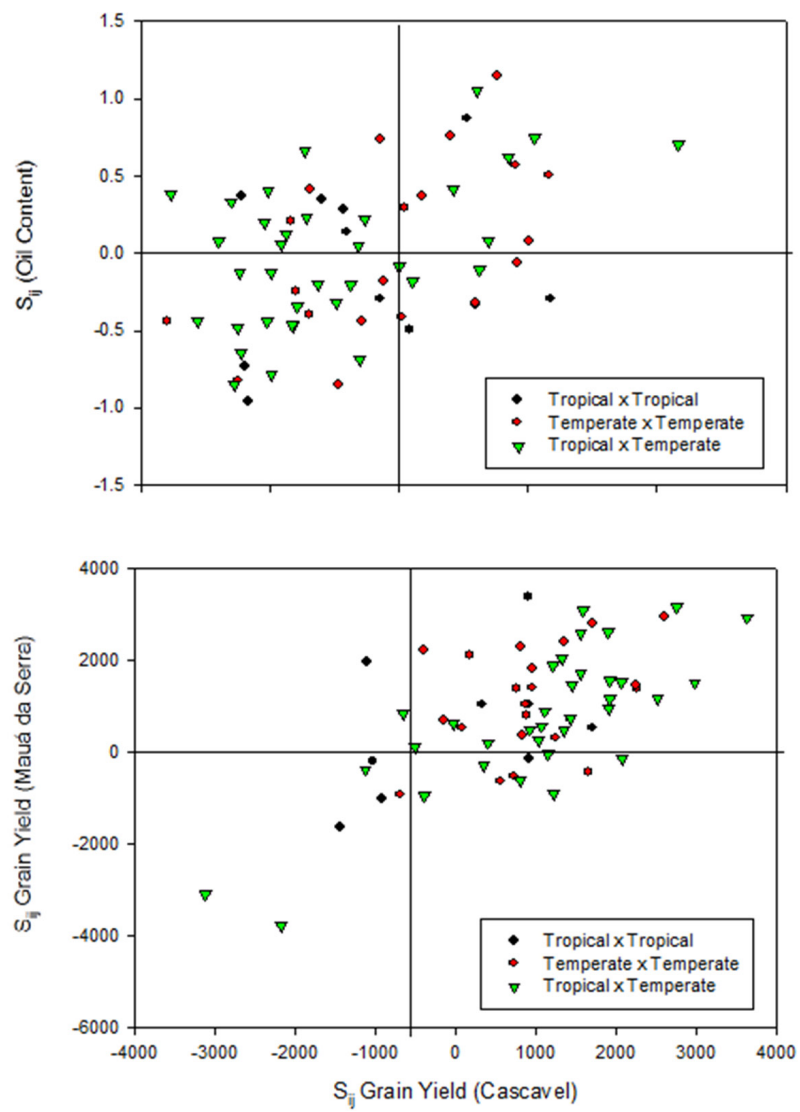

Figure 1. Estimates of the effects of specific combining ability for crude protein, oil content and grain yield evaluated in 12 maize inbred lines in a complete diallel scheme without reciprocals.
$\mathrm{L}_{12}$ ), temperate $\mathrm{x}$ temperate $\left(\mathrm{L}_{1} \times \mathrm{L}_{3}, \mathrm{~L}_{2} \times \mathrm{L}_{4}, \mathrm{~L}_{2} \times \mathrm{L}_{10}, \mathrm{~L}_{3} \times\right.$ $\mathrm{L}_{7}, \mathrm{~L}_{4} \times \mathrm{L}_{7}, \mathrm{~L}_{6} \times \mathrm{L}_{10}$ and $\mathrm{L}_{7} \times \mathrm{L}_{10}$ ) and tropical $\mathrm{x}$ temperate $\left(\mathrm{L}_{1} \times \mathrm{L}_{11}, \mathrm{~L}_{2} \times \mathrm{L}_{5}, \mathrm{~L}_{3} \times \mathrm{L}_{9}, \mathrm{~L}_{6} \times \mathrm{L}_{9}, \mathrm{~L}_{7} \times \mathrm{L}_{8}\right.$ and $\mathrm{L}_{7} \times \mathrm{L}_{9}$ ) these
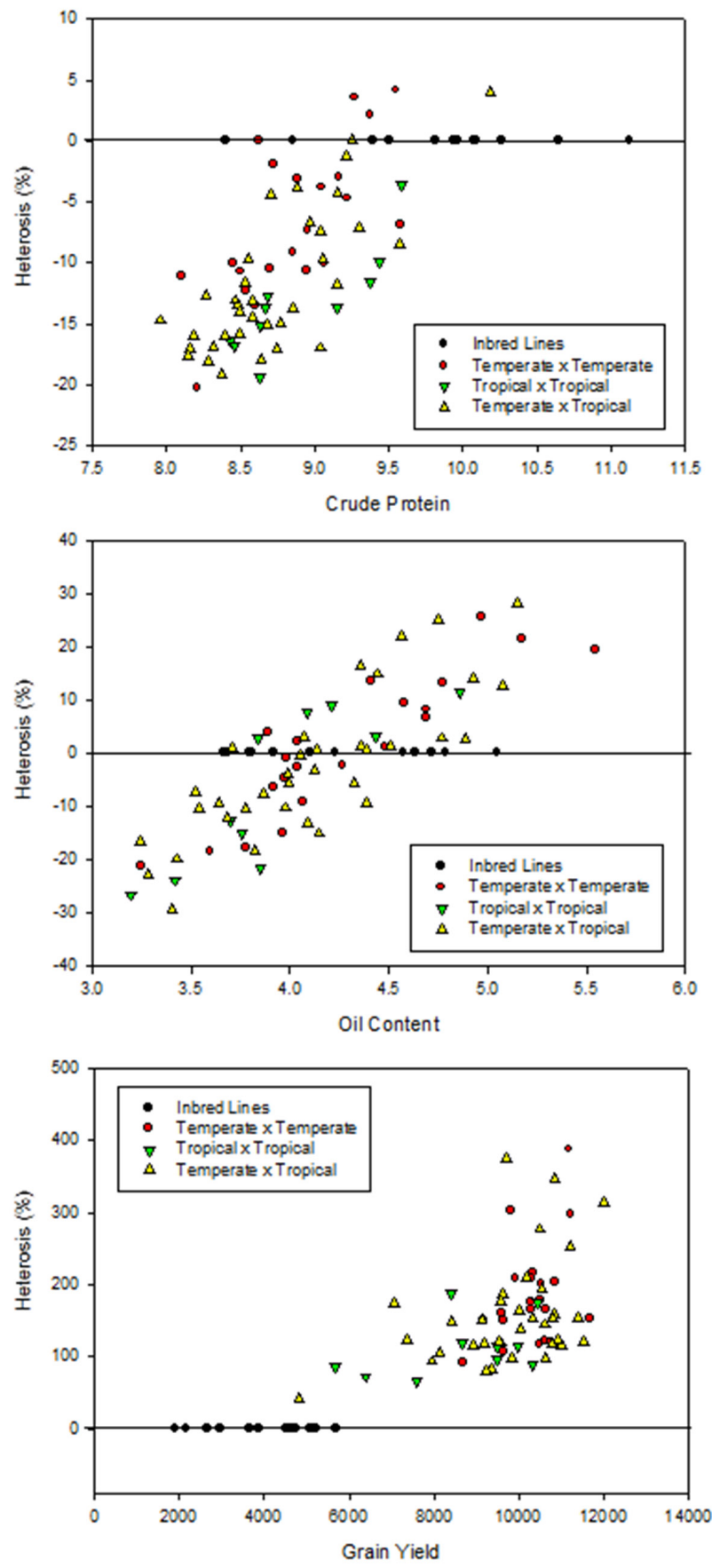

Figure 2. Heterosis percentage in relation to the percentage of crude protein, oil content and grain yield of 64 corn hybrids evaluated in a complete diallel scheme without reciprocals. 
$\mathrm{S}_{\mathrm{ij}}$ values were positive for crude protein and oil content (Figure 1). However, according to the estimates of the mean effect of GCA, only the lines $\mathrm{L}_{6}, \mathrm{~L}_{10}, \mathrm{~L}_{11}$ and $\mathrm{L}_{12}$ were higher for both traits, since the obtained values for $\mathrm{CP}$ and $\mathrm{OC}$ were positive and high. Thus, only the combinations $\mathrm{L}_{1} \mathrm{x}$ $\mathrm{L}_{11} \mathrm{~L}_{6} \times \mathrm{L}_{9} \mathrm{~L}_{2} \times \mathrm{L}_{10}$ and $\mathrm{L}_{6} \times \mathrm{L}_{10}$ are promising, since they have at least one superior parent for the average effect of GCA for the assessed traits.

The hybrids $\mathrm{L}_{1} \times \mathrm{L}_{10}$ (temperate $\mathrm{x}$ temperate) and $\mathrm{L}_{1} \mathrm{x}$ $\mathrm{L}_{12}, \mathrm{~L}_{4} \times \mathrm{L}_{8}$ and $\mathrm{L}_{2} \times \mathrm{L}_{8}$ (tropical $\mathrm{x}$ temperate), has excellent grain yields, with highest $\mathrm{S}_{\mathrm{ij}}$ in both environments (Figure 1.) In Cascavel, the $\mathrm{S}_{\mathrm{ij}}$ values for $\mathrm{GY}$ of the hybrids $\mathrm{L}_{1} \times \mathrm{L}_{11} \mathrm{~L}_{6}$ $\mathrm{x} \mathrm{L}_{9} \mathrm{~L}_{2} \times \mathrm{L}_{10}$ and $\mathrm{L}_{6} \mathrm{x} \mathrm{L}_{10}$ reached -1118.52, 406.16, 970.84 and 2267.46, respectively. In Mauá da Serra, the values were $-376.97,203.61,1804.44$ and 1433.18 , respectively.

Figure 2 presents the results of heterosis percentage in relation to $\mathrm{CP}, \mathrm{OC}$ and $\mathrm{GY}$ for 64 maize hybrids evaluated in a complete diallel scheme without reciprocals. The study of the possible manifestation of heterosis for $\mathrm{CP}$ showed a positive heterosis percentage for only four hybrids: $L_{1} \mathrm{x}$ $\mathrm{L}_{7}, \mathrm{~L}_{6} \times \mathrm{L}_{10}$ and $\mathrm{L}_{7} \times \mathrm{L}_{10}$ (temperate $\mathrm{x}$ temperate group) $\mathrm{L}_{1}$ $\mathrm{x} \mathrm{L}_{11}$ (temperate $\mathrm{x}$ tropical groups). Among these hybrids, only $\mathrm{L}_{1} \times \mathrm{L}_{7}$ obtained a positive heterosis value $(0.11)$. For OC, 31 hybrids had positive heterosis, ranging from 0.39 to $28.16 \%$. The $\mathrm{OC}$ was highest in the hybrids $\mathrm{L}_{6} \times \mathrm{L}_{10}, \mathrm{~L}_{2}$ $\mathrm{x} \mathrm{L}_{6}, \mathrm{~L}_{7} \times \mathrm{L}_{9}$ and $\mathrm{L}_{1} \times \mathrm{L}_{11}$, with 5.54, 5.17, 5.14 and 5.07\%, respectively, which had positive heterosis values.

For grain yield, heterosis ranged from 40.50 to $386.46 \%$, mainly for the hybrids $\mathrm{L}_{2} \times \mathrm{L}_{8}, \mathrm{~L}_{3} \times \mathrm{L}_{7}, \mathrm{~L}_{5} \times \mathrm{L}_{7}, \mathrm{~L}_{6} \times \mathrm{L}_{8}$, and $\mathrm{L}_{1} \times \mathrm{L}_{10}$, with a GY of $12008.55,11698.56,11525.36$, 11402.13 , and $11240.26 \mathrm{~kg} \mathrm{ha}^{-1}$, respectively. The combinations $\mathrm{L}_{1} \times \mathrm{L}_{11}$ and $\mathrm{L}_{6} \times \mathrm{L}_{10}$, with positive heterosis for CP and OC, reached GY of 8125.24 and $10645.97 \mathrm{~kg} \mathrm{ha}^{-1}$, respectively. Therefore, $\mathrm{L}_{6} \times \mathrm{L}_{10}$ was considered a promising hybrid because it associated grain yield positively with crude protein and oil content.

\section{Análise dialélica de linhagens de milho para rendimento de grãos, teores de óleo e proteína}

Resumo - O presente trabalho teve como objetivos investigar a capacidade combinatória e o efeito heterótico de linhagens tropicais e temperadas sobre o rendimento de grãos $(R G)$, teor de óleo (TO) e proteína (PB). Os híbridos e as linhagens foram avaliados a partir de um dialelo completo, sem recíprocos, em dois experimentos delineados em blocos casualizados com três repetições. $O$ desdobramento da soma de quadrado de genótipos em soma de quadrados para capacidade geral (CGC) e específica (CEC) de combinação e a subsequente constatação de significância de CGC e de CEC evidenciaram que tanto efeitos aditivos quanto não-aditivos estiveram envolvidos no controle genético das características avaliadas. Pelas estimativas dos componentes quadráticos, houve superioridade dos efeitos genéticos não-aditivos no controle das características. Contudo, percebe-se que para PB e TO o efeito não-aditivo influenciou negativamente as combinações híbridas. O cruzamento $L_{6} x L_{10}$ foi considerado promissor, pois associou positivamente RG com PB e TO.

Palavras-chave: Zea mays L., capacidade combinatória, heterose, método Griffing, melhoramento de plantas.

\section{REFERENCES}

Badu-Apraku B and Lum F (2010) The pattern of grain yield response of normal and quality protein maize cultivars in stress and nonstress environments. Agronomy Journal 102: 381-394.

Boyer CD and Hannah LC (2001) Kernel mutants of corn. In Hallauer AR (ed) Specialty corns. CRC, Boca Raton, p. 1-31.

Bueno LG, Chaves LJ, Oliveira JP, Brasil EM, Reis AJS, Assunção A, Pereira AF and Ramos MR (2009) Controle genético do teor proteico nos grãos e de caracteres agronômicos em milho cultivado com diferentes níveis de adubação nitrogenada. Pesquisa Agropecuária Brasileira 44: 590-598.

Compêndio Brasileiro de Alimentação Animal (2009) Editora Sindirações, São Paulo, 390p.

Cruz CD (2013) Genes - a software package for analysis in experimental statistics and quantitative genetics. Acta Scientiarum Agronomy 35: $271-276$.

Fan XM, Tan J, Chen HM and Yang JY (2003) Heterotic grouping for tropical and temperate maize inbreds by analyzing combining ability and SSR markers. Maydica 48: 251-257.

FAO (2013) Food and Agriculture Organization of the United Nations. Available at < http://www.fao.org/docrep/011/ai474e/ai474e02.htm> Accessed on Jan 31, 2013.

Gibbon BC and Larkins BA (2005) Molecular genetic approaches to developing quality protein maize. Trends in Genetics 21: 227-233.

Griffing BA (1956) Concept of general and specific combining ability in relation to diallel crossing systems. Australian Journal Biology Science 9: 463-493.

Gupta HS, Agrawal PK, Mahajan V, Bisht GS, Kumar A, Verma P, Srivastava A, Saha S, Babu R, Pant MC and Mani VP (2010) Quality protein maize for nutritional security: rapid development of short duration hybrids through molecular marker assisted breeding. Current Science 96: 230-237.

Gutiérrez-Rojas A, Betrán J, Scott MP, Atta H and Menz M (2010) Quantitative trait loci for endosperm modification and amino acid contents in quality protein maize. Crop Science 50: 870-879.

Jellum MD and Marion JE (1966) Factors affecting oil content and oil 
AJK Werle et al.

composition of corn (Zea mays L.) grain. Crop Science 6: 41-42.

Mangolin CA, Souza Júnior CL, Garcia AAF, Garcia AF, Sibov ST and Souza AP (2004) Mapping QTLs for kernel oil content in a tropical maize population. Euphytica 137: 251-259

Misevic D, Maric A and Alexander DE (1989) Population cross diallel among high oil populations of maize. Crop Science 29: 613-617.

Oliveira JP, Chaves LJ, Duarte JB, Brasil EM, Ferreira Júnior LT and Ribeiro KO (2004) Teor de proteína no grão em populações de milho de alta qualidade protéica e seus cruzamentos. Pesquisa Agropecuária Tropical 34: 45-51.

Osorno JM and Carena ML (2008) Creating groups of maize genetic diversity for grain quality: implications for breeding. Maydica 53:131-141

Prasanna BM, Vasal SK, Kassahun B and Singh NN (2001) Quality protein maize. Current Science 81: 1308-1319.

Uribelarrea M, Below FE and Moose SP (2004) Grain composition and productivity of maize hybrids derived from the Illinois protein strains in response to variable nitrogen supply. Crop Science 44: 1593-1600.

Zhang J, Lu XQ, Song XF, Yan JB, Song TM, Dai JR, Rocheford T and Li JS (2008) Mapping quantitative trait loci for oil, starch, and protein concentrations in grain with high-oil maize by SSR markers. Euphytica 162: 335-334. 